\title{
Pre-Test as a Stimulant to Learning for Undergraduates in Medicine
}

\author{
V. K. Sreelatha ${ }^{1}$, V. D. Manjula², R. Sajith Kumar $^{3}$
}

${ }^{1}$ Department of ENT, Government Medical College, Ernakulam, Kerala, India. ${ }^{2}$ Department of Community Medicine, Government Medical College, Ernakulam, Kerala, India. ${ }^{3}$ Department of Infectious Diseases, Government Medical

College, Kottayam, Kerala, India.

\section{ABSTRACT}

\section{BACKGROUND}

Effective learning occurs when students are interested to learn. Curiosity increases interest. Curiosity can be increased by posing a question. Pre-test has long been used to assess the knowledge before a course or workshop and post-tests helps to assess how much the participant has benefited. We wanted to find out the effectiveness of pre-test as a stimulant to learning in medical graduates.

\section{METHODS}

A class of students in $6^{\text {th }}$ semester MBBS is included in the study. One group of students was given pre-test and after the interactive lecture class all the students were given a post test and a follow up test was done after two weeks. All together 6 classes were taken with interchanging of groups. The results were analysed.

\section{RESULTS}

The analysis of the results revealed no significant difference in the retention of information by the students who got pre-test and those who didn't get. But regarding perception $70 \%$ of the students were of opinion that pre-test helped them to learn important points and also motivated them to be focussed on the lecture.

\section{CONCLUSION}

Analysis of the results did not reveal any significant difference in the retention of information among students of the two groups. The present study didn't reveal a significant difference in the scores of those students who got the pre-test and those who didn't get the pre-test. This may be attributed to the absence of students who got pre-test, at the time of follow up tests. Regarding perception, 70\% of students were of opinion that pre-test was an important method to learn important points and they could remain focussed on the lecture.

\section{KEY WORDS}

Pre-Test, Follow-Up Tests
Corresponding Author:

Dr. V. D. Manjula,

Professor,

Department of Community Medicine, Government Medical College,

Ernakulam, Kerala, India.

E-mail:vdmanju@gmail.com

DOI: $10.14260 / \mathrm{jemds} / 2019 / 841$

Financial or Other Competing Interests: None.

\section{How to Cite This Article:}

Sreelatha VK, Manjula VD, Kumar RK. Pretest as a stimulant to learning for undergraduates in medicine. J. Evolution Med. Dent. Sci. 2019;8(51):3886-3889, DOI: $10.14260 /$ jemds $/ 2019 / 841$

Submission 16-09-2019,

Peer Review 04-12-2019,

Acceptance 10-12-2019,

Published 23-12-2019. 


\section{BACKGROUND}

Effective learning occurs when the students are motivated to learn. It also depends on their interest to learn. It is known that curiosity arouses interest. One sided lectures are usually boring for the students and they lose attention after 15-20 minutes. By giving a pre-test students can be sensitised and it can act as stimulus to learning. Pre-test can increase attentiveness of students. Pre-test, post-test and follow up tests are usually used to evaluate the effectiveness of an intervention. In literature there are only few references about studies conducted to assess the effectiveness of pre-test as a stimulant to learning. Moreover, learning outcomes are better if students are actively involved. This study is conducted to find out the effectiveness of pre-test as a stimulant to learning and also to determine the perception of students about pretest and follow up tests.

We wanted to determine the effectiveness of pre-test as a stimulant to learning for $6^{\text {th }}$ semester MBBS students of Government Medical College, Ernakulam and determine the perception of students about pre-test and follow up tests.

\section{METHODS}

This is a quasi-experimental study conducted over a period of 2 months. The participants were $6^{\text {th }}$ semester MBBS students. Study setting is ENT lecture hall of Government Medical College Ernakulam. All students willing to participate in the study was included. The students who were absent in any of the tests were excluded

The approval of Institutional ethical committee was obtained. 80 students of $6^{\text {th }}$ semester MBBS students were included in the study. After getting an informed consent, the whole class was divided into two by lottery method. In the first class one group was given a peer validated questionnaire containing a set of 10 multiple choice questions covering the key points in the topic to be covered, and they were given 5 minutes to get familiarised with the questions. The questions were returned and the whole class was given an interactive lecture on the topic. Then the whole class was given a post test and scores recorded. The group which got the pre-test was termed group A and those without pre-test was termed group B. In the next class the groups were interchanged and the group which didn't get pre-test question was given the questions. After the interactive class all students were given post tests and scores recorded. Here again the pre-test group was named $A$ and the other group $B$

This was repeated for the next 3 classes also. Four weeks later a follow up test was comprising the whole 5 sets of questions and the scores recorded. The mean and standard deviation of the follow up test score for those who got pretest that is group A and group B who didn't get pre-test in each of the topics was calculated excluding the absentees. The results were calculated separately for each of the topics and finally the results were also calculated as a whole for the five tests. Those students who were absent for any of the tests were excluded from the study. In the last class, student's perception regarding the pre-test was taken on Likert's scale and the results expressed as frequency and percentage.

\section{Statistical Analysis}

The score of students in the follow up tests for both groups, those with pre-test and those without pre-test were recorded. The mean score for each test was calculated. The mean scores of all the five tests was also calculated. The mean scores were analysed using unpaired $t$ test Significant level was fixed at 5 $\%$. Perception of students were recorded on Likert's scale and was expressed as percentage.

\section{RESULTS}

The mean test score of those students with pre-test and those without pre-test was analysed using unpaired $t$ test. None of the tests had a p value less than 0.05 for individual tests (Table 1).

\begin{tabular}{|c|c|c|c|c|c|c|}
\hline & 气̊ & $\mathbf{z}$ & Е & மे & 苟离 & 2 \\
\hline \multirow{2}{*}{ Meniere's disease } & With pre-test & 32 & 4.91 & 2.414 & 0.427 & 1.061 \\
\hline & Without pre-test & 32 & 5.91 & 2.07 & 0.366 & \\
\hline \multirow{2}{*}{$\begin{array}{l}\text { Test for } \\
\text { hearing }\end{array}$} & With pre-test & 16 & 5.25 & 1.612 & 0.403 & 0.92 \\
\hline & Without pre-test & 32 & 5.19 & 2.416 & 0.427 & \\
\hline \multirow{2}{*}{$\begin{array}{c}\text { Conductive hearing } \\
\text { loss } \\
\end{array}$} & With pre-test & 26 & 1.42 & 1.77 & 0.347 & 3.06 \\
\hline & Without pre-test & 31 & 1.68 & 1.904 & 0.342 & \\
\hline \multirow{2}{*}{ SNHL } & With pre-test & 41 & 4.02 & 2.139 & 0.334 & 0.13 \\
\hline & Without pre-test & 24 & 3.21 & 2.000 & 0.408 & \\
\hline \multirow{2}{*}{$\begin{array}{c}\text { Rehabilitation } \\
\text { Of hearing impaired }\end{array}$} & With pre-test & 25 & 3.32 & 2.545 & 0.509 & 0.27 \\
\hline & Without pre-test & 35 & 2.63 & 2.143 & 0.362 & \\
\hline
\end{tabular}

\begin{tabular}{|c|c|c|c|c|c|}
\hline Group & $\mathbf{N}$ & Mean & S.D. & Std. Error Mean & p \\
\hline With Pre-test & 140 & 3.76 & 2.493 & 0.211 & 0.57 \\
\hline Without Pre-test & 154 & 3.59 & 2.535 & 0.204 & \\
\hline \multicolumn{7}{|c|}{ Table 2. Final Analysis of the 5 Tests } \\
\hline
\end{tabular}

\begin{tabular}{|c|c|c|c|c|c|c|}
\hline & $\stackrel{\overparen{8}}{0}$ & 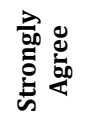 & 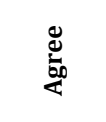 & $\begin{array}{l}\frac{\pi}{2} \\
z \\
己\end{array}$ & 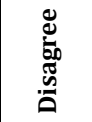 & 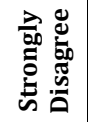 \\
\hline $\begin{array}{c}\text { Pre-test helped to be more } \\
\text { focused on lecture }\end{array}$ & 56 & $5(9 \%)$ & $36(64 \%)$ & $11(20 \%)$ & $3(5 \%)$ & $1(2 \%)$ \\
\hline $\begin{array}{c}\text { Pre-test helped to answer } \\
\text { the questions which they } \\
\text { did not know earlier }\end{array}$ & 57 & $4(7 \%)$ & $34(60 \%)$ & $14(24 \%)$ & $4(7 \%)$ & $1(2 \%)$ \\
\hline $\begin{array}{c}\text { Pre-test is an important } \\
\text { method to learn important } \\
\text { points }\end{array}$ & 58 & $8(14 \%)$ & $32(56 \%)$ & $14(24 \%)$ & $2(3 \%)$ & $2(3 \%)$ \\
\hline Pre-test is a waste of time & 59 & $2(4 \%)$ & $2(4 \%)$ & $20(34 \%)$ & $25(42 \%)$ & $10(16 \%)$ \\
\hline \multicolumn{7}{|c|}{ Table 3. Analysis of Perception Score } \\
\hline
\end{tabular}

\section{DISCUSSION}

The analysis of the results revealed no significant difference in the retention of information by the students who got pretest and those who didn't get. Though the individual results of test 2, 4 and 5 showed a better mean value for the students who got pre-test the result did not show a significant $p$ value. (Table-1) The final results also didn't show a significant $p$ value. (Table-2) Richland and others conducted a series of experiments and arrived at the conclusion that a) A failure in pre-test was found to increased retention of studied content, probably the pre-test directed the learner's attention to the key testable points in a passage. b) Second experiment showed that testing items before learning was a more potent 
learning opportunity than the provision of extended study time of the same items. Thus, testing appears to provide a unique benefit above and beyond directing learners' attention to content that has a high probability of being tested later. c) Attempting to answer a pre-question was significantly more effective than reading the same question and attempting to memorize it without making an attempt to retrieve the answer. Their study showed that pre-tested items were better retained at a final test one week later than those who were not pre-tested, the present study didn't show much difference in those pre-tested and not pre-tested. ${ }^{1}$

Some of the reasons that can be attributed to our test results can be-

1. Delay in conducting the follow up tests.

2. Difference in number of students attended and the difference in difficulty level of the topics.

3. There may be more intelligent students in the group without pre-test. In this study students were asked not to answer the pre-test questions rather they were asked just to get familiarised with the questions. May be this has also contributed to the present result.

Another prospective randomised control trial done at University of New South wales, Australia, showed that there was no measurable increase in learning with pre-test. In this study the study group was given subject specific multiplechoice questions as pre-test whereas the control group got a placebo pre-test. ${ }^{2}$

In a study conducted by Arun et al, the students were divided into two groups. One group was given pre-test and post-test and the second group got only post-test. Though the results were not statistically significant, those who got pretest scored better in the post test. ${ }^{3}$

It is human consciousness that motivates the person to learn, develop oneself, do well in life and help others. Students learn out of curiosity, desire to learn, challenge and social interaction in the classroom, at home and in society. The curiosity of students can be increased by giving a pretest. Interest is central to the learning process. When the students or learners are interested, they retrieve the information from the text or teacher or presenter which is of importance to them; store in memory and use it when required. 4

The cognitive benefits of testing after studying are well established to persist even when there is no opportunity to restudy information ${ }^{5}$. Tests can be used as learning events in educational settings and can be considered as a potential learning opportunity rather than an assessment measure. Pre-testing can lead to better retention. One of the advantages of pre-test is that it directs students' attention to information.

Considering the KWL (know - wants to know - learned) also the" wants to know" part can be by the pre-test which tells the learner what all things has to be learned.

According to nine steps of instructional design proposed by Gagne and others the first step is gaining attention of students. According to him attention can be gained by various measures of which posing questions to them is one? The second step would be to inform the students about the objectives of the class that is what all things they need to learn from the class. Both these gaining attention and informing them about the things to learn can be accomplished by giving questions prior to the class. This will also sensitise them and make them more focused ${ }^{5}$.

Curiosity arouses interest and questions can be given to generate curiosity. In another study, pre-test and post-test were included with lecture class and this was found to increase the attentiveness of students. ${ }^{6}$ The Study by Hogan clearly demonstrates the advantage of sensitising the students mind with the pre-test. Pre-test can enhance learning. Pre-testing encourages more active involvement in learning perhaps by generating interest in the topic. It may help students to recognise what type of information is important and what the teacher is going to teach.7

There are only few references on studies on pre-test as a stimulus to learning. The variety of ways to enhance learning are not easily enumerated or categorized, but one general and enduring principle is that active involvement in learning creates lasting memories. Literature on cognitive psychology has put forward many theories and testing effect is one among them. In this testing is thought to increase the ability to remember things better and also to retain the information for a longer time thus enhancing learning. ${ }^{8}$ Another study by Roediger also mentions that tests helps to improve memory by retrieving the information and helps to improve the learning of contents through long term retention of received information. This is called test enhanced learning. ${ }^{9}$

The efficacy of test enhanced learning as a learning tool in lectures to undergraduate medical students was studied at a randomised control trial conducted at Yusra Medical \& Dental College Islamabad, Pakistan. The study concluded that the test enhanced learning did significantly improve the learning of course content delivered to the students. They also recommend test enhanced learning as an effective tool for promoting learning and enhancing long term memory of undergraduate students. ${ }^{10}$

Testing effect is one of those, which states that when the students are tested for a specific content, they remember it better and for longer time period than the content not tested at al. Tests not only strengthen the memory by retrieving the information but also improve the learning of contents through long-term retention of specific information. This phenomenon is known as Test-Enhanced Learning.

Testing information on a studied material provides a measure of learners' knowledge and also the tested information is better retained than the information from further study. Even if tests are not answered successfully, they have the potential to improve future learning, as measured by both immediate and delayed performance measures. This finding suggests that using tests as learning events in educational settings could have lasting benefits for learners' content acquisition, and that tests should be considered a potent learning opportunity, rather than simply as an assessment measure.

In a study by Preselyey et al there were 3 groups. In this one group was asked to answer pre-questions second group allowed to read the pre-questions and the third was kept as a control group. The students who were made to answer the pre-test questions performed better than the control group. The group who were made only to read the pre-questions did not have any significant advantage over the control group. The results were consistent with the perspective that activating prior knowledge can positively affect learning ${ }^{11}$. 
Ralph e Reynolds in his study mentions about the theory which states that readers selectively allocate a greater volume of attention to question relevant information. Additional attention also causes more of the information to be learned. ${ }^{12}$

\section{CONCLUSIONS}

Though similar studies have shown pre-test to be of value in retention of information, contrary to the expectations, the analysis of results of the present study did not figure pre-test as a stimulant to learning. This may be because of the limiting factors. But regarding perception, $73 \%$ of students were of opinion that pre-test helped them to get more focussed on the lecture.

\section{Limitations}

As the students were having only one hour allotted for the ENT subject in a week, closer scheduling of class was not possible. The follow up test which was scheduled to be conducted at 2 weeks could not be conducted due to technical reasons at the stipulated time and had to be conducted later. This could have affected the results. Some students who were present at the time when pre-test was given were absent at the time of follow up test. Proximity of the follow up test to the sessional examination could also have influenced the results of follow up tests. Possibility that intelligent students were more in the group which did not have the pre-test could also have affected the results.

\section{ACKNOWLEDGEMENT}

Authors thank their students of GMC Ernakulam for participating in the study.

\section{REFERENCES}

[1] Richland LE, Kornell N, Kao LS. The pre-testing effect: Do unsuccessful retrieval attempts enhance learning? J Exp Psychol Appl 2009;15(3):243-57.
[2] Hill DA. Role of pre-test in the progressive assessment of medical students. Aust N Z J Surg 1992;62(9):743-6.

[3] Mohanram AM, Zhong Q, Singh T, et al. Evaluating the effectiveness of pre-test and post-test model of active learning in a medical school. FASEB Journal Published Online: 1 Apr 2015.

[4] Khobragade S, Khobragade Y. Study on impact of interest and motivation in learning outcomes in higher education. American Research Thoughts 2016;2(5):3613-20.

[5] Gagné RM, Briggs LJ, Wager WW. Principles of instructional design. $4^{\text {th }}$ edn. Forth Worth, Texas: Harcourt Brace Jovanovich College 1992.

[6] Muthukumar S, D'cruz SM, Anandarajan B. Introduction of pre-test and post-test enhances attentiveness to physiology lectures - students' perceptions in an Indian Medical College. Int J Biomed \& Adv Res 2013;4(5):3414.

[7] Hogan RM, Kintsch W. Differential effects of study and test trials on long-term recognition and recall. Journal of Verbal Learning and Verbal Behavior 1971;10(5):562-7.

[8] Butler AC, Roediger 3rd HL. Testing improves long-term retention in a simulated classroom setting. Eur J Cogn Psychol 2007;19(4-5):514-27.

[9] Roediger HL, Karpicke JD. Test-enhanced learning: taking memory tests improves long-term retention. Psychol Sci 2006;17(3):249-55.

[10] Ayyub A, Mahboob U. Effectiveness of Test-Enhanced Learning (TEL) in lectures for undergraduate medical students. Pak J Med Sci 2017;33(6):1339-43. doi:10.1080/09541440701326097. [Google Scholar

[11] Presley M, Tanenbaum R, McDaniel MA, et al. What happens when university students try to answer prequestions that accompany textbook material? Contemporary Educational Psychology 1990;15(1):2735.

[12] Reynolds RE, Anderson RC. Influence of questions on the allocation of attention during reading. Journal of Educational Psychology 1982;74(5):623-32. 